\title{
The Philosopher Cameo
}

\author{
By Trine Riel
}

Fall 2015 Issue of KINEMA

\section{THE PHILOSOPHER CAMEO}

Within current film studies a distinction is made between what are termed respectively "philosophy of film" and "film as philosophy" (or in some extreme cases "filmosophy"). ${ }^{(1)}$ While philosophy of film refers to a philosophical study of films, "a discussion of philosophical problems related to film, its nature, effects, and value", film as philosophy proposes the medium of film itself as a mode of philosophising, a way of doing philosophy. ${ }^{(2)}$ What the film as philosophy thesis proposes, in short, is that some works of film "through means exclusive to cinema" can be understood to make concrete, epistemological contributions to philosophy that are just as rigorous as traditional philosophical propositions expressed linguistically. ${ }^{(3)}$ And further, that it is not by citation of existing philosophical texts, or by having a recognised philosopher talk on screen, that a film can be said to align itself with philosophical activity: Merely "downloading" philosophical content onto a film's soundtrack does not make the film itself a philosophical proposition but only a representation of one. ${ }^{(4)}$ Rather, if film can be said to produce philosophy, to engage in philosophical practice proper, it must instead be by its own, that is by cinematic, means.

This article will not consider whether or not film can do philosophy or if doing philosophy can in fact be identified with the production or formulation of propositions. It aims instead at what is, in many ways, a more straightforward investigation. Rather than viewing works of film from a philosophical perspective, the following will focus on how the philosopher, as the embodied representative of the philosophical discipline, appears within a filmic context. While the film-as-philosophy thesis states clearly that the auditory presence of a philosopher or philosophical text within works of cinema does not make the film themselves do philosophy, this essay, by analysis of two examples, aims to demonstrate how the representation and appropriation of the philosopher figure on screen can be seen to reflect on the nature of philosophical activity, and on the role of the philosopher persona in a wider context.

There are, I propose, three predominant modes of representation of the philosopher figure within fiction film, which can be classified as follows:

1. A known philosopher played by an actor. This category includes the blockbuster hit Alexander (in which Christopher Plummer stars as Alexander the Great's teacher Aristotle) as well as examples from the biopic genre such as Derek Jarman's Wittgenstein (written with Terry Eagleton), Liliana Cavani's Beyond Good and Evil or the more recent Hannah Arendt by Margarethe von Trotta.

2. A known philosopher playing a fictive character. This covers films in which a known philosopher plays an (often minor) role within the film's fictional narrative, such as Gilles Deleuze in Michele Rosier's George qui?, the young, and by then unknown, Giorgio Agamben in Pier Paolo Pasolini's The Gospel According to Matthew and Marxist philosopher Antonio Negroes in the French fashion designer Agnes B's My name is Hmmm...

3. A known philosopher playing himself. This third category presents the figure of the philosopher in a more ambiguous role, casting him or her in between fiction and fact as a cameo. ${ }^{(5)}$ Examples are Marshall McLuhan in Annie Hall, Bertrand Russell in the Bollywood film Man, Henri Laborit presenting his behaviourist theories in Resnais' Mon oncle d'Amérique and Robert Solomon lecturing on existentialism in the animated movie Waking Life.

The article will treat two works belonging to this third category: Jean-Luc Godard's Vivre sa vie (1962) and Ken McMullen's Ghost Dance (1983), which feature philosophers Brice Parain and Jacques Derrida respectively playing themselves. The following discussion on the representation of the (male) philosopher cameo will not cover the wider narrative or overall aesthetics of the two films, but will only treat the specific scenes in which Derrida and Parain appear, in order to examine and compare how the figure of the philosopher 
is portrayed and put to use in the two films, being doubly indexed as actor and commentator and as fictive and real-life persona.

Jean-Luc Godard has made repeated use of the philosopher cameo. In La Chinoise (1967) Francis Jeanson features in conversation during a train journey while Alain Badiou can be seen lecturing without an audience in Film Socialisme (2010). French existentialist philosopher of language Brice Parain appears in chapter 11 of Godard's Vivre sa vie: Film en douze tableaux (1962), entitled "Place du Châtelet - the stranger - Nana is doing philosophy without knowing it".

The opening scene sees the film's tragic protagonist Nana, played by Godard's muse and partner Anna Karina, entering a Parisian café. She sits down by herself and after a brief moment initiates a conversation with an older man (Parain) who is reading Freud at the next table. ${ }^{(6)}$ Nana starts out with curious yet trivial questions such as "Do you come here often?" and "What are you doing?" - to which the philosopher responds "sometimes" and that he is "reading". After telling Parain that he "looks bored" she asks if he would mind buying her a drink. Having used up her small talk Nana now confesses to Parain that she suddenly finds herself "not knowing what to say", a comment which causes their conversation to enter a new stage, their dialogue developing into a self-reflexive meditation on the nature of speech, its relation to thought, action and everyday life.

During the seven-minute scene, the fictive character of Nana and the real-life figure of Parain who, as the chapter's title indicates, remains a "stranger" to the protagonist, perform a live philosophical drama in which both interlocutors assume their respective roles: Nana as the young, inquiring protégée asking earnest questions, and Parain as her older, pedagogical mentor who attempts to give thoughtful responses. Listening to Parain, Nana goes through various stages of comprehension, sometimes responding with frustration ("Why must one always talk?"), at other times failing to understand ("Why are you telling me this story?"), and at other moments again drawing her own partial, and correct, conclusions from Parain's philosophical reflections ("Then thinking and speaking are the same thing?"). When asking if silence would not be the preferable way of living, Parain melancholically answers, "Perhaps, but can one? I've found that we can't live without talking.... We must think and for thought we need words. To communicate is our lives" to which Nana genuinely responds, "Yes, but it is very difficult." This difficulty, as Parain explains to Nana, is exactly what she experienced at the start of their conversation as a momentary crisis of language, an instant where, as Parain describes, "one searches and cannot find the right word..."

The dialogue between Parain and Nana does not only serve as an occasion to reflect theoretically upon the problems of speech, but simultaneously presents a dialectic enactment of them. The difficulty of expression is both discussed and experienced by Nana as a consequence of the encounter with the philosopher, who in turn acts both as the teacher who explains the nature of this difficulty to Nana and as the figure who actively brings it about. The contemplative process that the philosopher figure instigates is here proposed as inhibiting Nana's ability to continue the automated small talk she began with, By making Nana's speech aware of itself, Parain at the same time, for a moment at least, paralyses it. As Parain describes to Nana: "We pass from silence to words, that's the movement of life.... From everyday life one rises to a life we call superior. The thinking life. But this life presupposes one has killed everyday life."

By Parain's inclusion of Nana in the philosophical dialogue he invites her to take part in "thinking life". A generous invitation which nevertheless plunges her into a melancholy state, where she "searches and cannot find the right word". This experience of a linguistic crisis is proposed as the initiating event which ultimately brings Nana to philosophy, makes her a philosopher, although an unwitting one; someone who philosophises without knowing it, as proposed by the chapter's title. Nana's experience of "thinking life", however, is not suggested as inert. As opposed to Parain, whose demeanour is calm and focused, Nana appears selfconscious and distracted with her legs fidgeting under the table and while Parain's eyes remain fixed on his conversation partner throughout, she casts impatient glances around the room and eventually directly into the camera. The scene's portrayal of Nana suggests how the internal process of comprehension that she undergoes, as a direct effect of her dialogue with the philosopher, is outwardly expressed in self-conscious gestures, momentary loss of concentration and the restless movements of her body. Nana's mannerisms are shown as analogous to, or as the embodied manifestation of, an intellectual digest, proposing philosophical dialogue and thinking as such, as an uneasy process of incorporation and further, it reflects what Godard 
himself said of the film: "In Vivre sa vie I have attempted to film a mind in action, the interior of someone seen from outside." ${ }^{\prime 7}$

The insertion of the philosopher in Vivre sa vie serves several functions. Firstly, a clear narrative one. It is an occasion to let Nana express herself, thus opening her character up to the audience. Nana's conversation with Parain is the only time in the film where she is allowed to speak about and reflect on her feelings and their chance meeting presents a sincere and moving moment in the film, where Nana's vulnerability becomes aligned with Parain's melancholic reflections on solitude, silence and the difficulty of language. The scene where Nana does philosophy without knowing produces an intimate event between the two interlocutors, an intimacy which is transferred unto the viewer by Nana eventually neglecting Parain and gazing into the lens of the camera. This at the same time alludes to a second function of the philosopher cameo. Nana's interaction with the real-life philosopher not only forces her character out of the sphere of spontaneous, natural speech, but brings about an alteration, or collapse, of its fictive structures. The suggested contrast between "everyday life" and "thinking life" becomes parallel to the contrast between the sphere of acting to which Nana belongs and the authenticity of Brice Parain, who is understood not to be acting, except as himself. By her interaction with the philosopher cameo, whose double indexing positions him as a figure caught between fact and fiction, his ambiguous dimension is transmitted to the character of Nana, revealing the actual, real-life presence of the actress Anna Karina.

Nana, who as an effect of her meeting with the philosopher finds herself no longer "knowing what to say", is not only alienated from everyday speech but from the scripted lines necessary for upholding her appearance as a simulated character within the fictional narrative. The effect of the philosopher cameo in Vivre sa vie thus creates a both intimate and estranged image of the tragic protagonist. He acts as an occasion for the audience to gain access to the character of Nana's inner life and at the same time for openly revealing her as a staged construct, thus alienating her and the audience from the fictitious realm of the film itself. This is further affirmed by the fact that Nana and Parain are never shown within the same frame and their conversation therefore gives a strong appearance of having been edited together afterwards. The scene, for all its sincerity, at the same time openly suggests that Parain, at the time of filming, was in fact in conversation with Godard and not Nana - or for that matter Karina. This adds a third function of the philosopher cameo in Vivre sa vie: It is a strategic intervention which in addition to revealing Nana's "mind in action" and breaking down her fictional character, exposes Godard, the director, as the actual interlocutor of Parain - as someone who is knowingly "doing" philosophy.

Ken McMullen's experimental film Ghost Dance (1983) features Jacques Derrida not only in the cameo role of revered philosophy professor, but also, by the title's reference to Derrida's theories on the concept of hauntology, as an explicit source of inspiration for the film itself. ${ }^{(8)}$ McMullen has since repeated his filmic engagement with contemporary French philosophy in his later film An Organization of Dreams (2009) in which Bernard Stiegler, a former collaborator of Derrida, plays a prominent role. ${ }^{(9)}$ Ghost Dance's rejection of a sharp distinction between fiction and documentary is a theme shared with the works of Derrida and clearly echoes the films of Godard. The presentation of the philosopher cameo in Ghost Dance is in many ways similar to that of Vivre sa vie and Derrida's appearance in the film might even be called "Godardian".(10)

The context where the philosopher first appears in Ghost Dance is, again, an almost empty Parisian café. The film's protagonist, a young female named Pascale (played by French actress Pascale Ogier, who passed away shortly after the making of the film), is a student brought to the cafe by her professor in order to be introduced to Jacques Derrida. Before their arrival, the philosopher is filmed waiting alone, his pouting and uneasy glances into the camera a reminder of the self-conscious demeanour of Nana. This uneasiness also permeates the first and very short meeting between Derrida and Pascale which, unlike Nana's chance meeting with Parain, has been prearranged. Pascale already knows of the philosopher Jacques Derrida who, in turn, is introduced to Pascale by their shared acquaintance, the university professor, as someone who "has interesting ideas", ideas which the professor encourages Derrida to talk to her about. This makes for an unfruitful introduction and their forced exchange begins and ends with Pascale's attempt to answer Derrida's question, "What is the idea behind your idea?" She replies that the idea behind her idea is that she has "no idea", to which Derrida responds that they can talk about it tomorrow. End scene. This apparent failure of communication shows up two things: First, a seemingly ironic comment on the elliptical, some would say absurdist, character of Derrida's style of philosophy: the idea behind the idea is that there is no idea. 


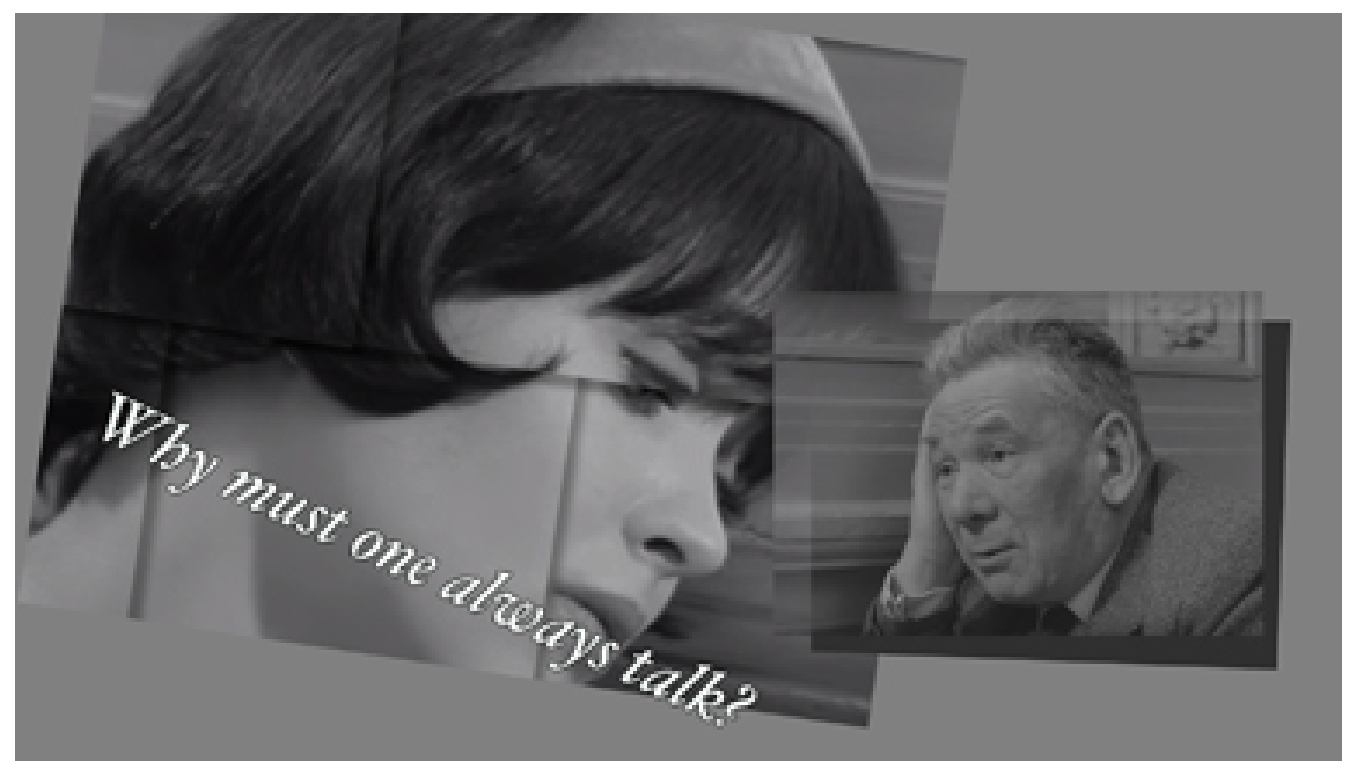

Figure 1: Vivre sa vie by Jean-Luc Godard (1962)

Secondly, that Pascal and Derrida are unable to enter into any natural, spontaneous dialogue, precisely because the set-up of their encounter has already been established as a situation where a philosophical conversation is expected to take place. Because Derrida, in sharp contrast to Parain's anonymity, has already been named and referenced several times, and because Pascale, unlike Nana, is a knowing student of philosophy with, as her professor says, original ideas of her own, there is no possibility for the two to meet as strangers, outside of the already established philosophical structure. They are both positioned in a specific relation to one another: one as a famous philosopher, the other as a promising student, and both of them as individuals familiar with, and involved in, academic philosophical practice.

Their next, and much longer, meeting takes place in the philosopher's office, where Derrida is sitting behind his desk. After Pascale's initial question, "Do you believe in ghosts?", Derrida's speech unfolds not so much in dialogue with the young student as a near monologue in which he makes explicit, self-referential comments on his appearance:

"Since I've been asked to play myself in a film that is more or less improvised, I feel as if I'm letting a ghost speak for me. Curiously instead of playing myself... without knowing it... I let a ghost ventriloquise my words, or play my role which is even more amusing."

Shortly after this statement, the phone rings and the audience (together with Pascale) overhears Derrida's supposedly real-life conversation with an unnamed caller about a seminar the following day. As in the earlier scene, a pre-established structure frames this second and final meeting - this time in the concrete form of an office and the allusion to a future seminar. Whereas Parain had only his Freud book as reference point, Derrida is surrounded by texts, papers and books, by his academic life and engagements. A background which firmly positions Derrida in his own individual space as a professional philosopher. As opposed to Vivre sa vie where Parain is inserted into the fictional realm and the everyday life of Nana, Pascale is the only supposedly fictional element within the otherwise unambiguously "real" setting of Jacques Derrida's office.

In contrast to Nana's naïve curiosity, the character of Pascale is portrayed as reserved and there is no trace in her demeanour of someone undergoing an internal process of reflection, confusion or comprehension. As reflected in Pascale's lack of response to Derrida throughout their conversation, the philosopher is not presented as having the ability to operate within the fictional sphere of the film but is firmly positioned outside of it. This outside positioning of Derrida at the same time shows up the main function of the philosopher cameo in Ghost Dance. Just as Parain and Nana's dialogue performatively addressed what they were themselves doing, namely trying to vocalise their thoughts to communicate philosophically, what 
Derrida addresses in his conversation with Pascale relates to what he is doing, namely appearing within a filmic sequence of images. Whereas Parain's cameo transmitted an alteration to the fictive character Nana, the conversation between Pascale and Derrida allows for the latter to reflect on his own presence, and to transform himself into "a ghost". Derrida, as he explains, is not "playing himself" but rather, "without knowing it", is letting a ghost speak his words and thus play his role.

Derrida's cameo, due to his external position, introduces a meta-level from which it becomes possible for the philosopher to simultaneously appear in and present a philosophical commentary upon his own appearance in Ghost Dance. By presenting himself as a phantasmal presence, he produces an endless loop of selfreferentiality relating back to his own theories of the spectral nature of filmic images. In order to do this, and in order to propose himself as someone who is "not playing himself", he nevertheless relies on a referencing of himself, and thus on an implicit upholding of his position as a persona belonging to the non-fictional sphere of his office, his books, his telephone calls. Ken McMullen's appropriation of Derrida can be seen in this way to lend the philosopher figure a certain authority. Not only are Derrida's ideas presented as being a main inspiration for the film, but by letting Derrida himself explain what his on-screen presence means and how we, as an audience, should perceive it - as a ghost ventriloquising Derrida's words - he is allowed more or less full control over what function his appearance serves in Ghost Dance. Derrida's role in Ghost Dance is, in other words, reliant on the fact that both Pascale and we as viewers acknowledge Jacques Derrida as a philosopher, or at least recognise him as a public persona.

Vivre sa vie and Ghost Dance show very similar representations of the philosopher figure in terms of what he does, where, and with whom. In both films we encounter the philosopher in indoor settings associated with intellectual life. In the context of deserted Parisian cafés and academic offices, both films confirm another classic theme related to philosophical activity - the Socratic dialogue - which sees the philosopher teacher in a verbal exchange with a younger, inquisitive partner. The stationary nature of the settings of these dialogues is further reflected in the cameras' more or less fixed focus. The two philosophers are framed as disembodied talking heads and we never see either Parain or Derrida in movement; in fact we never see them get up from their seats. Both Vivre sa vie and Ghost Dance thus to a great extent affirm a traditional image of the philosopher as a scholarly person removed from the sphere of action, a person who, as exemplified by Parain, spends his time reading books or as affirmed by Derrida, delivers university seminars.

There are however clear differences in the two films' strategic usage of the philosopher cameo. While Parain's anonymity - the fact that he is never named and remains a stranger to the protagonist - allows him to perform a clear narrative function in terms of revealing Nana's character to the audience as both vulnerable and staged, Jacques Derrida, on the other hand, does not help reveal anything about Pascale. Positioned outside of, and therefore unable to penetrate, the film's affective realm, he is incapable of producing any emotive reaction in the characters he encounters. This set-up is further reflected in the fact that in Ghost Dance the protagonist can only access Derrida through a mediated and academic frame of reference: in the setting of his office or by being introduced by other university professionals. This is in stark contrast to Vivre sa vie which presents the philosopher as someone immediately accessible outside of any professional structures, as someone who willingly and patiently engages with a non-philosopher's private and existential questions.

While Derrida's identification as an intellectual persona whose reputation precedes him is what allows him to make meta comments upon the filmic construct from within, it excludes him from the possibility of engaging sincerely with, or to in any way assist, the protagonist in her project. As Pascale explains to her female companion later in the film, "I once studied with Derrida, but in the end he could not help me. There are certain things that men don't understand you know," - a comment which can be seen as a rebellious dismissal of the intellectual authority Derrida has been given throughout the film. Whereas Godard generously, and idealistically, presents the philosopher as someone who can serve as an ally for the conflicted non-philosopher, it could be suggested that Ghost Dance, in (perhaps unwitting) accordance with Pascale's conclusion, indirectly presents a dismissive characterisation of the philosopher as a figure who, by his exclusion from the fictive realm, is symbolically removed from the sphere of embodied, gendered life, and thus ultimately useless when it comes to offering any guidance pertaining to everyday life and action.

Derrida does, however, prove highly useful to Ghost Dance on a different level. It is apparent that in Vivre sa 
vie is Godard and not Nana who is having a conversation with the philosopher. Although Pascale and Derrida, unlike Karina and Parain, do appear in the same frame, the stilted exchange between them suggests that as in Vivre sa vie, it is the filmmaker McMullen who is in actual dialogue with the philosopher. In both cases, the on-screen appearance of the philosopher playing himself presents moments in which the two directors directly express their own personal interest in, and admiration for, the two respective canonical French thinkers Parain and Derrida, whose real-life presence in turn lends a certain intellectual merit to the films in which they appear. This is especially apparent in Ghost Dance, where Derrida's cameo, while being impotent within the fictional narrative, serves an influential if not dominating role in relation to the film's thematic and conceptual concerns. The philosopher figure in this way shows himself as an exceptional tool for revealing, not the "mind in action" of Vivre sa vie's protagonist, but rather McMullen's own intellectual intentions. He becomes a vehicle for transmitting complex theories about the nature of cinematic representation, about the production of images and the act of starring within them. The two directors' appropriation of the philosopher cameo suggests that the philosopher figure has the potential to serve as a useful ally for the filmmaker, as an instrument for thinking about cinema within the cinematic medium itself, for staging a dialogue between the supposedly intellectual activity of philosophy and the practice of filmmaking.

The question of whether or not Vivre sa vie and Ghost Dance can be said to 'do philosophy', in the manner described at the beginning, must be left for the defenders of the film-as-philosophy thesis to judge. But what is perhaps most interesting in Vivre sa vie's and Ghost Dance's engagement with and representation of the philosopher, is that the on-screen presence of Parain and Derrida activate a questioning of the philosopher figure in regard to his relevance and capacity outside of the academic structure. Regardless of whether the two films do philosophy, they present a critical reflection on themselves and on what philosophy is or can be, at least as rigorously and insightfully as any theoretical inquiry expressed by traditional textual means.

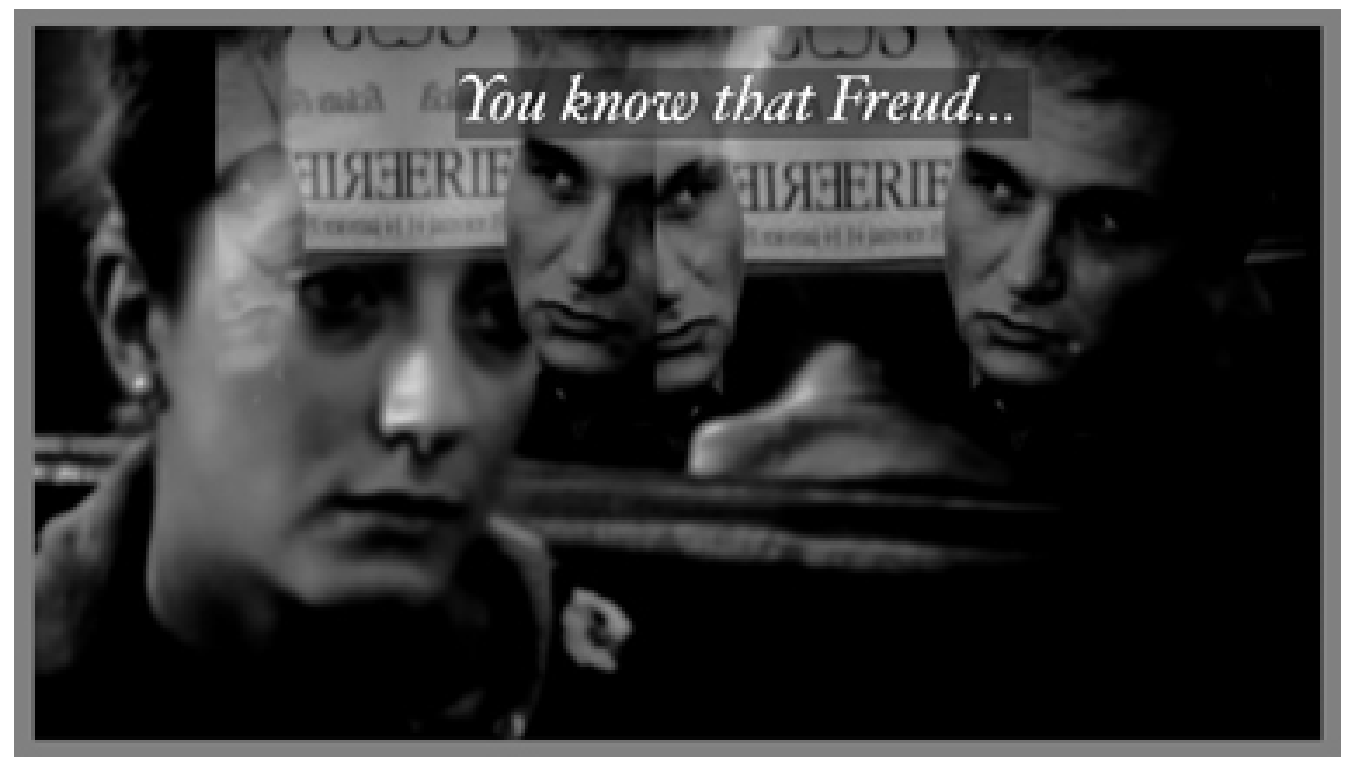

Figure 2: Ghost Dance by Ken McMullen (1983)

\section{Notes}

1. See Frampton, "Notes on Filmosophy: A Reply to Reviews".

2. Aron Smuts, "Film as Philosophy: In Defense of a Bold Thesis".

3. See Paisley Livingston, "Theses on Cinema as Philosophy". One of the problems with the film-asphilosophy thesis is the implicit aligning of "philosophical practice" with the linguistic formulation of propositions and more generally of "philosophy" with the production of "knowledge". The equation of knowledge 
with philosophical knowledge means, as Murray Smith amongst others point out, "closing a gap" that is problematic. A problem which Smith, however, does not manage to resolve in his text "Film, Art, Argument and Ambiguity".

4. Noël Carroll quoted in Smuts "Film as Philosophy: In Defense of a Bold Thesis". Smuts uses Godard's Weekend as an example of a film not being philosophical "in the relevant sense".

5. It has not been possible to find any examples of the female philosopher cameo on film. Although Catherine Malabo for example appears in the recent film Love in the Post (Dir. Joanna Callahan), her presence in the film is not strictly speaking a cameo.

6. As noted by Lack in "Vivre sa vie: An Introduction and A-Z" Sigmund Freud's Three essays on sexuality is not visible in the film, but can be seen in the production stills.

7. Godard quoted in Roland-Francois Lack "Vivre sa Vie: An Introduction and A-Z" in Senses of Cinema issue 48

[ http://sensesofcinema.com/2008/before-the-revolution/vivre-sa-vie-a-to-z/ ] Accessed $1^{\text {st }}$ September 2015.

8. See Ken McMullen's website [ https://kenmcmullenfilms.wordpress.com/ghost-dance/ ] Accessed $1^{\text {st }}$ September 2015.

9. Derrida and Stiegler worked together on Echographies of Television: Filmed Interviews. See also the interview with Stiegler in which he discusses Derrida's theories on Hauntology in relation to Ghost Dance. Available on youtube

[https://www.youtube.com/watch?v=hXQB7RFzoFM] Accessed $1^{\text {st }}$ September 2015.

10. "Derrida's cameo is, it must be said, very Godardian (...) the scene is haunted by Godard" Tyson Stewart "Spectral Media in Ken McMullen's Ghost Dance (1983) and Zina (1985)" available on academia.edu

[ https://laurentian.academia.edu/TysonStewart ] Accessed 1 ${ }^{\text {st }}$ September 2015.

\section{References}

\section{Bibliography}

Derrida, Jacques and Stiegler, Bernard. Echographies of Television: Filmed Interviews. Trans. By Jennifer Bajorek. Cambridge; Polity Press 2002 (originally published in French 1996).

Frampton, Donald. "Notes on Filmosophy: A Reply to Reviews." In New Review of Film and Television Studies, 2008, Vol.6(3), pp 365-374.

Lack, Roland-Francois. "Vivre sa vie: An Introduction and A-Z". In Senses of Cinema, issue 48 (August 2008).[http://sensesofcinema.com/2008/before-the-revolution/vivre-sa-vie-a-to-z/]

Livingston, Paisley. "Theses on Cinema as Philosophy". In The Journal of Aesthetics and Art criticism, 2006, Vol 64(1), pp 11-18.

Smith, Murray. "Film, Art, Argument and Ambiguity". In Smith/ Wartenberg (ed.) Thinking Through Cinema: Film as Philosophy, pp. 33-43. Malden; Blackwell Publishing 2006.

Smuts, Aaron. "Film as Philosophy: In Defense of a Bold Thesis". In The Journal of Aesthetics and Art Criticism, 2009, Vol. 67(4), pp. 409-420.

Stewart, Tyson. "Spectral Media in Ken McMullen's Ghost Dance (1983) and Zina (1985)". On academia.edu.[http://www.academia.edu/9711403/Spectral_Media_in_Ken_McMullen_s_Ghost_Dance_1983_and_Zina

Stiegler, Bernard. Interview "Bernard Stiegler on Jacques Derrida, Hauntology and Ghostdance" Paris, 2006. [https://www.youtube.com/watch?v=hXQB7RFzoFM]

\section{Filmography}

Al di la del bene e del male (Beyond Good and Evil). Liliana Cavani. Les Artistes Associés; France/Italy 1977. 
Alexander. Oliver Stone. Warner Bros; US 2004.

Man. Mohan Kumar. Amar Jyoti Pictures; India 1967.

An Organization of Dreams. Ken McMullen. Augustine Pictures; UK 2009.

Annie Hall. Woody Allen. United Artists; US 1977.

Film Socialisme. Jean-Luc Godard. Wild bunch; France 2010.

George qui? (George Who?). Michele Rosier. NEF; France 1973.

Ghost Dance. Ken McMullen. Channel 4/ZDFUK; UK/ West Germany 1983.

Hannah Arendt. Margarethe von Trotta. NAP, Sophie Dulac, Zeitgeist; Germany/ Luxemburg/ France 2012

Il Vangelo secondo Matteo (The Gospel according to Matthew). Pier Paolo Pasolini. Titanus Distribuzione; Italy 1964 .

Je m'apelle Hmm... (My name is Hmm...) Agnès B. A3 Distribution; France 2013.

La Chinoise. Jean-Luc Godard. Athos Films; France 1967.

Love in the Post: From Plato to Derrida. Joanna Calaghan. Heraclitus Pictures; UK 2014.

Mon oncle d'Amérique. Alain Resnais. Les Films Galatée, Gaumont; France 1980.

Vivre sa vie; film en douze tableaux (My Life to Live). Jean-Luc Godard. Panthéon Distribution; France 1962 .

Waking Life. Richard Linklater. Fox; US 2001.

Wittgenstein. Derek Jarman. Les Films de l'Atalante, Uplink, Zeitgeist; France/Japan/ US 1993.

\section{Reports}

Photo credits: Vivre sa vie: Les Films de la Pléiade; Ghost Dance: Channel Four Films.

\section{Author Information}

Trine RIEL is a video artist and PhD student at The Huston School of Film \& Digital Media, National University of Ireland, Galway. Her research explores non-standard modes of philosophy and the possible intersections of academic and artistic practices. 